\title{
OFICINA: REVISÃO DE FRAÇÕES E NÚMEROS DECIMAIS PARA ALUNOS DO $7^{\circ}$ E $8^{\circ}$ ANOS
}

\author{
Giovana Rafaela Hasstenteufe ${ }^{1}$ \\ Fernanda Zorzi ${ }^{2}$
}

\section{INTRODUÇÃO}

Este artigo refere-se à um relato de experiência vivenciadas durante a aplicação da oficina desenvolvida por uma aluna do curso de Licenciatura em Matemática do Instituto Federal do Rio Grande do Sul - Campus Bento Gonçalves, com as turmas de sétimo e oitavo anos da Escola Estadual de Ensino Médio Assunção, no período de quatro encontros com duração de uma hora cada, totalizando quatro horas.

A comunicação, o ato de saber se comunicar, é fundamental, através dela que podemos demonstrar o que sentimos (o que está bom ou o que está incomodando). Pensando desta forma, logo garantimos a sua importância no ambiente escolar, pois conhecer os alunos e entender o que eles estão sentindo é fundamental para que se obtenha um resultado satisfatório na aprendizagem da turma. Segundo Campos (2015): “(...), no âmbito escolar onde a educação falha, ela traz resultados desastrosos.”.

Durante o período de pandemia o ato de se comunicar ficou diferente, ocorrendo estritamente através das telas dos computadores. Sabe-se que todo o contato e o convívio presente dentro da sala de aula é fundamental para o processo de aprendizagem dos alunos, mas tanto os alunos como os professores tiveram que se adaptar a este novo meio de ensinar e aprender.

\footnotetext{
I Instituto Federal do Rio Grande do Sul- IFRS Campus Bento Gonçalves. E -mail: giovana.rafaela.h@outlook.com

2 Instituto Federal do Rio Grande do Sul- IFRS Campus Bento Gonçalves. E -mail: fernanda.zorzi@bento.ifrs.edu.br
} 


\section{FUNDAMENTAÇÃO TEÓRICA}

Por diversas vezes durante as aulas quando os professores estão explicando algum conteúdo matemático, este se depara com o questionamento da turma querendo saber aonde aquilo vai ser usado em sua vida, acredito que este pode ser o primeiro fator a ser citado pelos índices baixos em aprovação nesta disciplina.

Para que que exista a aprendizagem, a informação recebida precisa despertar o interesse do aluno, ou seja, aquela informação precisa fazer sentido. (CAMPOS,2015). É necessário que ele saiba por que está aprendendo sobre isso e por que isso se torna importante na sua trajetória escolar.

Perante isso, é necessário transmitir que a Matemática surgiu pela necessidade do homem em fazer contas. Esta informação precisa estar clara para os alunos. A maioria deles relatou que com os jogos houve um interesse maior em estudar sobre a Matemática, este é um ponto positivo, pois conhecendo mais em relação a esta disciplina, é possível compreender melhor os conteúdos, interligando com o seu surgimento e também entender que houve muitos estudos para chegar à matemática que conhecemos hoje, ou seja, nada surgiu pronto ou foi inventado. (CAMPOS,2015)

Mas o educador deve estar ciente de que pode existir alunos em suas turmas com dificuldades em compreender o raciocínio lógico e que, para esses alunos são necessárias outras formar para ensinar os conteúdos. (CAMPOS, 2015).

Segundo (CAMPOS, 2015): "Durante as atividades lúdicas, o professor deve ser um observador, permitindo que as crianças joguem pelo simples prazer de jogar, sem interferir ou premeditar a realização do jogo.”. Nesse sentido, uma das alunas relatou no questionário que sentiu falta de ser acompanhada pela professora nos jogos.

Como os jogos desenvolvem a autonomia, acredito que foi por este motivo esta resposta, pois neles não tinha a possibilidade da professora resolver ou de copiar de algum colega, assim os próprios alunos tinham que pensar referente as questões ou em 
seus grupos. Esta foi a finalidade de não interferir durante os jogos: trabalhar com a autonomia e com a tomada de decisões da turma.

\section{RESULTADOS ALCANÇADOS}

Esta oficina foi elaborada com o intuito de proporcionar uma revisão dos seguintes conteúdos: Operações com Frações e Operações com Números Decimais. A mesma foi elaborada para duas turmas, uma turma de sétimo ano e uma turma de oitavo ano.

Os assuntos abordados na oficina foram selecionados com base nas dificuldades que a professora observou nas turmas citadas. Sendo eles: Operações com Frações, o cálculo de Mínimo Múltiplo Comum e Operações com Números Decimais. Ela foi desenvolvida de forma remota, através do Google Meet utilizando o powerpoint como ferramenta para elaboração das aulas.

A oficina durou quatro encontros de uma hora cada, ocorrendo sempre nas terças-feiras, tendo início dia 27/04/2021 e término dia 18/05/2021. A turma do sétimo ano é composta por onze alunos e a turma do oitavo ano por vinte e dois alunos.

Todas as aulas ocorerram de maneira semelhante, iniciando com a explicação através de slides e no final dos encontros foram aplicados jogos online contendo exercícios de fixação do conteúdo. Os jogos utilizados são do WordWall, apenas foram adaptados para as aulas realizando algumas alterações.

De modo geral, os alunos que participaram da Oficina demonstraram bastante interesse e atenção nas aulas. Se comunicavam basicamente através do chat de mensagens.

ATIVIDADE r: Eliminando somas e subtrações de frações 
Nesta atividade, os alunos deveriam encontrar a resposta correta da conta que aparecia. Encontrando a resposta, aquele resultado será eliminado.

\section{ATIVIDADE 2: OPERAÇÕES COM FRAÇÕES}

Esta atividade é bastente semelhante à atividade anterior. Os alunos abriam uma caixa e deveriam encontrar a resposta correta da conta que aparecia.

ATIVIDADE 3: Multiplicação e Divisão com frações

A proposta desta atividade é a seguinte: os alunos arrastam a conta no seu respectivo resultado.

ATIVIDADE 4: Loteria dos decimais - Adição e Subtração

Esta atividade mostrava uma conta e haviam três alternativas. Na hora já mostrava se o aluno marcou a resposta correta ou não.

ATIVIDADE 5: Operações com números decimais

Os alunos abriam uma caixa e deveriam encontrar a resposta correta da conta que aparecia. Haviam seis alternativas.

\section{CONCLUSÕES}

Com este trabalho pode-se receber um bom retorno dos alunos, demonstravam entender com facilidade as explicações e na hora de realizarem os exercícios também não apresentavam dificuldades. Esta oficina colaborou também na minha formação docente, pois cada proposta de ensino colabora na construção do conhecimento, nos tornando mais preparados para enfrentar os desafios encontrados na docência, principalmente neste momento, em que os professores tiveram que se adaptar ao ensino remoto. 


\section{PRINCIPAIS REFERÊNCIAS BIBLIOGRÁFICAS}

CAMPOS, Ana Maria Antunes de. JOGOS MATEMÁticos: UMA NOVA PERSPECTIVA PARA DISCALCULIA. Rio de Janeiro: Wak Editora, 2015.

CAMPOS, Ana Maria Antunes de. DISCALCULIA: SUPERANDO AS DIFICULDADES EM APRENDER MATEMÁTICA. 2. ed. Rio de Janeiro: Wak Editora, 2015.

JÚNIOR, José Ruy Giovanni; CASTRUCCI, Benedicto. A Conquista da Matemática. São Paulo: FTD S.A., 2009. 